\title{
ТЕРРИТОРИАЛЬНЫЕ СВЯЗИ, ГНЕЗДОВОЙ КОНСЕРВАТИЗМ, ДИСПЕРСИЯ И ФИЛОПАТРИЯ КУКШИ РЕRISOREUS INFAUSTUS (PASSERIFORMES, AVES) В ЯКУТИИ
}

\author{
Егоров Н. Н., Гермогенов Н. И., Секов А. Н., Лосоров А. В. \\ ФГБУН Институт биологических проблем криолитозоны СО РАН, г. Якутск \\ E-mail: sterkh-yrcu@mail.ru
}

\begin{abstract}
Исследования проводились на двух видовых модельных площадках (471 и 1360.3 га) в среднетаежных светлохвойных лесах близ г. Якутск (62 c. ш., 129 в. д.) в 1975-2015 гг. Кукша обитает в разнообразных ландшафтных условиях и весьма пластична при выборе гнездового участка и места для устройства гнезда. Для значительной части размножающихся птиц характерен консерватизм, проявляющийся в наличии постоянных мест круглогодичного обитания, размещения гнездовых участков и устройства гнезд. Данные индивидуального мечения свидетельствуют о том, что большинство птенцов покидали модельные площадки (погибали, эмигрировали). Лишь небольшая доля молодых птиц удерживалась в локальной популяции, присоединяясь в качестве третьего «инертного» партнера к территориальным парам, а позднее, обретя партнера и территорию, включалась в состав репродуктивной популяции.
\end{abstract}

Ключевые слова: кукша, территориальные связи, гнездовой консерватизм, натальная и гнездовая дисперсии, Центральная Якутия.

DOI: 10.34078/1814-0998-2020-4-97-104

\section{ВВЕДЕНИЕ}

Кукша - моногамный одиночно гнездящийся вид с хорошо выраженным гнездовым консерватизмом. Характер оседлости вида меняется в зависимости от ландшафтно-экологических особенностей местности. В одних условиях вид способен совершать широкие кочевки на зиму в более южные районы (Владимирская, 1948; Blomgren, 1971; Андреев, 1980), в других, как, например, в Мурманской области (Коханов, 1982) и Центральной Якутии (Егоров и др., 2019), кукша ведет более оседлый образ жизни. У молодых птиц дважды в год наблюдаются локальные кочевки. Они имеют сезонный характер и обычно происходят в конце зимы - весной и в конце осени - начале зимы.

Несмотря на широкое распространение и относительно высокую численность в подходящих местообитаниях, по многим аспектам биологии кукша по-прежнему остается одной из малоизученных птиц отечественной фауны. Это связано с особенностями репродуктивной биологии: для вида характерно воспроизводство (откладка яиц, насиживание, вылупление птенцов) в условиях низких температур и снежного покрова.

(C) Егоров Н. Н., Гермогенов Н. И., Секов А. Н., Лосоров А. В., 2020
В основу данной работы положены материалы, собранные в 1987-2015 гг. на двух модельных площадках (далее - площадки), заложенных в разных типах среднетаежных светлохвойных лесов близ г. Якутск. Наблюдения базировались на кольцевании птиц и дальнейшем прослеживании особей и пар в различные сезоны и их участия в воспроизводстве локальных популяций. Итоги этих работ опубликованы авторами в цикле сообщений, которые касаются в основном биологии гнездования, структуры населения и динамики численности вида в условиях Центральной Якутии (Ларионов и др., 1980; Гермогенов и др., 2013, 2014, 2015, 2017, 2018; Егоров и др., 2019). По вопросам филопатрии и территориального консерватизма опубликованы лишь предварительные результаты наблюдений (Гермогенов и др., 2002).

В настоящее время сравнительные материалы по территориальным связям птиц и особенностям освоения ими местообитаний можно найти лишь по кукшам Фенноскандии (Blomgren, 1971; Cramp, Perrins, 1994; Ekman et al., 2002; Uimaniemi, 2004; Griesser et al., 2014; Ekman, Griesser, 2016) и северо-западных областей России (Коханов, 1982; Правосудов, 1984; Семенов-Тян-Шанский, Гилязов, 1991). Данное сообщение восполняет пространственный раз- 
рыв в изучении вида на примере птиц, обитающих в условиях крайне континентального климата Якутии.

\section{МЕТОДЫ И МАТЕРИАЛ}

Общие сведения о площадках, включая места их размещения и биотопические характеристики, методах наблюдения и объеме собранных материалов получили достаточно подробное освещение в упомянутых выше публикациях. В работе использованы общепринятые в популяционной биологии термины и понятия (Ковшарь, 1979; Соколов, 1988; Рябицев, 1993; Паевский, 2008; и др.). Для конкретизации территориальных связей птиц (пар) с отдельными структурными компонентами среды обитания и полноты их анализа мы используем термин «территория обитания», а для обозначения предпочитаемых мест гнездования - словосочетание «места размещения гнезд».

Исследуемые площадки отличались ландшафтно-экологическими условиями. Различались также численность населения птиц, особенности устройства гнезд и их размещения на участке, а также сроки размножения и величина кладки (Гермогенов и др., 2017; Егоров и др., 2019).

Первая площадка (6154' с. ш., $129^{\circ} 55^{\prime}$ в. д.) имела площадь 471 га, включая 389 га древеснокустарниковых местообитаний. Здесь наблюдения выполнялись в 1987-1992, 2001, 2009 г. Площадка располагалась на правобережье р. Лена в 18 км юго-восточнее г. Якутск (Гермогенов и др., 2002). Вторая площадка находилась на ЛеноВилюйском междуречье $\left(62^{\circ} 06^{\prime}\right.$ с. ш., $129^{\circ} 16^{\prime}$ в. д.) и имела площадь 1360.3 га, включая 980.0 га древесно-кустарниковых местообитаний. Здесь наблюдения проводили в 2009-2015 гг. (Гермогенов и др., 2013, 2014, 2015, 2017; Егоров и др., 2019).

На площадке № 1 преобладали зрелые хвойные (сосновые и сосново-лиственничные) леса, практически отсутствовали болотины и водоемы. Она непосредственно прилегала к долине Лены, оказывающей отепляющее влияние на ее территорию. Гетерогенность местообитаниям придавали тропинки и дороги, пролегающие через площадку просеки с телефонными линиями и линиями электропередачи. Площадка № 2 занимала участок водораздельной тайги, подвергнутый значительной фрагментации для устройства пашен, которые составляли около 14\% ее территории. Кроме того, на площадке располагались три крупных аласа, занимавшие 9.3\% площади участка. Здесь преобладали сосновые и лиственничные леса, присутствовали характерные для междуречья заболоченные кочкарниковые низины, небольшие озера, водотоки и болотины с густыми зарослями кустарниковых ив - излюбленными участками для устройства кукшами гнезд. Температура воздуха на площадке всегда была примерно на $2^{\circ} \mathrm{C}$ ниже, чем в долине Лены. На площадке № 1 кукши гнездились с большей плотностью и строили гнезда преимущественно на деревьях, большинство пар начинали откладку яиц раньше и имели кладки несколько большей величины, чем на площадке № 2 (Гермогенов и др., 2017; Егоров и др., 2019).

Кукш метили металлическими и цветными (пластиковыми) кольцами, отлавливая на привадах (свиной жир), ежегодно выставляемых на короткий срок в конце зимы и осенью, а также вблизи гнезд. Всего пометили 375 экз., включая 160 птенцов: на площадке № 1 - 116 (61), № 2 - 259 (99). В ходе наблюдений устанавливали характер пребывания птиц на площадках, а по крайним точкам встреч, иногда - по возвратам колец, границы и площади территории обитания репродуктивных особей и пар.

При анализе связей гнездящихся птиц с породами кустарников и деревьев использованы данные по 288 гнездам, найденным в Якутии, включая незавершенные и брошенные. Из них на модельных площадках и прилежащих к ним территориях исследовано 245 гнезд: на площадке № 1 - 91 гнездо (в т. ч. включая найденные в 1975-1986 гг.), на площадке № 2 - 154 гнезда.

На площадке № 2 по 144 найденным гнездам выявлены 33 гнездовых участка. В 27 из них в 2009-2015 гг. с различной регулярностью размножались 39 пар (в т. ч. 36 пар, идентифицированных по кольцам). В 22 случаях гнездились не идентифицированные птицы. Эти наблюдения позволили вычислить примерную площадь гнездового участка, что не представилось возможным сделать ранее. По расположению 135 гнезд (от 2 до 13 на гнездовой участок, $\mathrm{n}=22$ ), принадлежащих 35 парам кукш (с учетом пар, в которых произошла смена партнера), определены площади мест размещения гнезд как структурных компонентов гнездового участка и параметры $\partial u c$ персий. «Натальная» дисперсия установлена для 16 молодых птиц, окольцованных птенцами (40 измерений расстояний), и «гнездовая», т. е. удаление гнезд у 25 пар по 43 измерениям расстояний между новыми гнездами и первым из обнаруженных.

При сборе и обработке материалов использовались GPS навигаторы и спутниковые снимки Google Earth Pro (CGoogle), стандартные методы биологической статистики (Лакин, 1980; Гланц, 1999) с применением пакета Microsoft ${ }^{\circledR}$ Excel и программы AtteStat v.12.5.

В разные годы в исследованиях участвовали орнитологи Института биологических проблем 
криолитозоны - к. б. н. Н. А. Находкин и И. Ю. Осипов, которым мы выражаем нашу искреннюю признательность.

\section{РЕЗУЛЬТАТЫ И ИХ ОБСУЖДЕНИЕ}

Прочные территориальные связи характерны для особей-«резидентов», давно осевших на территории, для пришлых птиц, ведущих оседлый образ жизни, и для птиц местного происхождения, составляющих основу видового населения (Егоров и др., 2019). Анализ этих связей свидетельствует о наличии у кукш перекрывающихся территорий обитания, используемых вне сезона размножения вместе с другими «резидентами», а также особями, прикочевавшими извне - «иммигрантами». Последние ежегодно появляются на участке, иногда на короткий срок, иногда гнездятся, придавая населению определенную динамичность. На территории обитания репродуктивной пары располагается гнездовой участок с одним или несколькими местами размещения гнезд, в которых в период размножения могли находиться лишь примкнувшие к ним в качестве третьего («пассивного») партнера одиночные птицы из числа «иммигрантов» или птенцов местного приплода, чаще от других родительских пар (Егоров и др., 2019).

Территория обитания. Кольцеванием взрослых кукш в Кандалакшском заповеднике Мурманской области установлено, что каждая пара занимает определенную территорию, на которой живет в течение нескольких лет (Коханов, 1982). В Лапландском заповеднике окольцованные в сентябре 1959 г. кукши были отловлены на том же месте: одна - через полгода, другая - 3 мес. спустя. Кукша, помеченная сеголетком в сентябре 1959 г., повторно отловлена на прежнем месте месяц спустя, затем - в марте следующего года (Семенов-Тян-Шанский, Гилязов, 1991). В Якутии птица, окольцованная в долине Средней

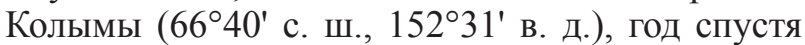
была поймана в том же самом месте (уст. сообщ. А. Г. Дегтярева).

На наших модельных площадках репродуктивные «резиденты» держатся в районе месторасположения своих гнезд круглогодично. На площадке № 2 у 15 окольцованных гнездящихся особей, наблюдаемых в течение 2-6 лет (в среднем 4.7), площадь территории обитания колебалась от 13 до 130 га (в среднем 52 \pm 9 га). При этом у самцов она была несколько больше, чем у самок: $58 \pm 13$ га (24-130 га, n=8) и 46 \pm 13 га (13-117 га, $\mathrm{n}=7)$.

В Мурманской области пары имеют сходные по площади территории обитания - от 45-57 (Коханов, 1982) до 50-70 га (Правосудов, 1984). Однако и в Фенноскандии (Blomgren, 1971), и на Колыме (Кречмар и др., 1978; Андреев, 1980) они больше - соответственно 1.5 и около 1 км². А. Бломгрен считает, что зимой пары пользуются наибольшими по размерам территориями обитания (Blomgren, 1971).

В негнездовой период территории обитания соседних пар перекрываются. Необходимо учитывать, что на этих территориях держатся и не размножающиеся птицы, составлявшие на площадке № 2 в среднем 50.4\% населения в целом и $36.5 \%$ - в сезон гнездования.

Гнездовой участок пары. С учетом размеров площадки № 2 (1360.3 га) и числа потенциально пригодных для гнездования участков - 33 (при условии 100\%-ной занятости), площадь последних составила в среднем 41.2 га. За вычетом открытых пространств - 190 га пашен и 126 га аласов, фактическая площадь гнездового участка кукши была меньше и составила 31.6 га.

На 27 участках, наиболее полно исследованных в 2009-2015 гг., с различной регулярностью размножались 39 пар кукши, включая 36 идентифицированных пар, зарегистрированы 22 случая гнездования не идентифицированных птиц. В пределах гнездового участка пары во время ее размножения другие кукши, за исключением третьего, «инертного» партнера, не регистрируются.

Продолжительность использования гнездового участка парой (не обязательно одной и той же) составляла $4.7 \pm 0.3$ сезона. На одном участке птицы гнездились 1 сезон $(3.7 \%)$, на трех $2(11.1 \%)$, на двух - $3(7.4 \%)$, на двух $-4(7.4 \%)$, на десяти $-5(37.0 \%)$, на шести - $6(22.2 \%)$ и на трех $-7(11.1 \%)$ сезонов.

Идентифицированные пары были зарегистрированы на всех выявленных гнездовых участках. Пары этой группы, также не всегда одни и те же (от 1 до 3), гнездились на участке от 1 до 6 (в среднем $3.8 \pm 0.3)$ сезонов. Не идентифицированные («неизвестные») пары отмечены на 19 участках $(70.4 \%)$ - от 1 до 2 пар на участок, занимая его в среднем $1.2 \pm 0.1$ сезона. На трех участках (11.1\%) в течение трех сезонов по одному разу гнездились неокольцованные пары, вероятно, «иммигранты». При этом 8 участков $(29.6 \%)$ в течение $1-6$ сезонов (в среднем $3.7 \pm 0.6$ ) занимали только персонализированные пары (до двух разных пар), в среднем $1.4 \pm 0.2(\mathrm{n}=11)$.

Оставление парой участка связано либо с гибелью птиц, либо с их дальними перемещениями, но последнему нет свидетельств. Тем не менее часть репродуктивных пар-«резидентов» способна менять гнездовые участки.

Наблюдения за 10 парами кукш на площадке № 1 показывают, что территориальный консерватизм прослеживается в 78.3\% случаев гнездования $(\mathrm{n}=23)$. Смена участка отмечалась у одной из наблюдаемых пар дважды: на 4-м и 5-м году наблюдений, у остальных - после 1-го $(\mathrm{n}=2)$ и 
2-го $(\mathrm{n}=10)$ сезонов гнездования. Пары занимали участок в течение $1-3$ лет $(1.8 \pm 0.1, \mathrm{n}=5)$ и перемещались на новый, не занятый предыдущими хозяевами участок в течение $1-4$ лет $(1.8 \pm 0.6$ лет; $\mathrm{n}=5)$.

На площадке № 2 из 35 идентифицированных и занимающих 22 гнездовых участка пар 9 гнездились в течение 1-го сезона (1 пара исчезла, 4 распались, 4 гнездились в 2015 г.), 14 пар 2-3 сезона, 4 пары - 4 и 3 пары - 5 сезонов (1-5 сезонов, в среднем $2.4 \pm 0.2$ ). На изначально выбранных гнездовых участках многократно - от 2 до 5 сезонов, держалось не менее 83.9\% пар (за вычетом 4 пар, гнездившихся впервые в последний год наблюдения). При этом 13 из 35 пар имели на участке за сезон по нескольку гнезд - ложных, недостроенных и повторно-вынужденных (с брошенными незавершенными кладками): у 11 пар это наблюдалось в период 1-го сезона размножения (8 пар - по 2 гнезда, 3 пары - по $3)$, у одной - 2 (по 2 гнезда) и еще одной пары в течение всех 3 сезонов гнездования. В 20132015 гг. сохранившиеся из распавшихся пар и не покинувшие свои участки птицы (6 самок и 3 самца) сформировали 9 новых пар. 7 из них регистрировались на гнездовье в течение одного сезона: одна на площадке более не наблюдалась, 2 - распались, 4 - гнездились в последний год наблюдений. Две другие новые пары занимали прежний участок партнера (в одном случае самки, во втором - самца) в течение двух последующих сезонов наблюдения. Смена гнездовых участков у постоянных пар на площадке № 2 наблюдалась только при смене партнера. В одном случае самец занял с новой самкой соседний с предыдущим участок, в другом - самка поочередно гнездилась с разными партнерами на четырех также соседних участках.

Смена «хозяев» участка характерна для вида и в других частях ареала. В Мурманской области (Коханов, 1982) за 13 лет на одном участке сменилось 5 пар, на другом - 2, занимавшие их 2-7, в среднем 4 года, по причине гибели самки, изгнания самца другими парами и разорения гнезд. Предельный срок пребывания пары на участке в Фенноскандии - 12 лет (Blomgren, 1971).

Места размещения гнезд. Кукши строят гнезда в определенных местах занимаемого участка, как правило, хорошо освещенных и укрытых от ветра, например, вдоль лесных дорог и опушек. На площадке № 2 птицы (34 пары) на участке $(\mathrm{n}=21)$ размещали гнезда $(\mathrm{n}=133)$ на площади 0.2

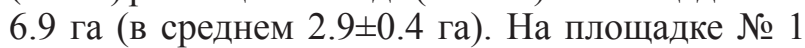
18 многократно гнездившихся на 15 участках пар строили гнезда $(\mathrm{n}=76)$ на заметно меньшей площади - 0.07-5.4 га (в среднем 1.8 \pm 0.4 га).

На площадке № 1 кукши гнездились преимущественно в сосновых и сосново-лиственничных борах, на площадке № 2 - в ивняках и лиственничниках. При этом птицы отличались предпочтениями в выборе древесно-кустарниковых пород, в первом случае устраивая гнезда в основном на соснах $-62.6 \%$ и лиственницах $-33.0 \%$ $(\mathrm{n}=91)$, во втором - на кустарниковых ивах (в основном иве Бэбба, часто засыхающих) $-57.0 \%$ и лиственницах $-35.4 \%(\mathrm{n}=144)$ (Гермогенов и др., 2017). То же наблюдалось у отдельных пар в пределах одного и того же гнездового участка. На площадке № 1 вероятность их смены составляла у идентифицированных пар 50\% (Гермогенов и др., 2002). На площадке № 2 почти всегда одну и ту же растительную породу выбирали 12 из 25 пар (48\%). Из них 8 строили гнезда на ивах (2 пары по два сезона каждая, 3 - в течение трех, 2 - четырех и $1-5$ сезонов, в среднем $3.2 \pm 0.3$ ), 3 - на лиственницах (3 пары по два сезона) и 1 - на сосне (6 сезонов). У одной пары это отмечено в 2015 г. трижды (с учетом повторновынужденного гнездования).

Предпочтения изменились у трех пар, в которых произошла смена самок, и то не у всех сразу. Одна из них в первый год по-прежнему гнездилась на сосне, на второй год - вначале на сосне, а затем, при повторно-вынужденном гнездовании, устроила гнездо на иве. Другая пара, отмеченная в первый сезон наблюдения на иве, во второй сезон дважды строила гнезда на деревьях (вначале на лиственнице, затем на сосенке). Только самец третьей пары, ранее два сезона размножавшейся на лиственницах, со сменой самки загнездился на иве, росшей среди мелкого лиственничника. Остальные 13 пар на протяжении 2-4, в среднем $2.9 \pm 0.2$ сезона $(\mathrm{n}=38)$, гнездились с различной регулярностью то на иве, то на лиственнице. По наблюдениям В. Д. Коханова (1982), в Мурманской области одна пара кукш устраивает гнезда поочередно на различных породах деревьев.

Дисперсия. Сроки и дальность натальной дисперсии значительно варьируют (Cramp, Perrins, 1994; Ekman et al., 2002; Griesser et al., 2014). Лишь в исключительных случаях сеголеток может оставаться на территории родителей, когда они вскоре после вылета птенцов из гнезда одновременно погибали. Подобное отмечено в Швеции всего дважды за 20 лет наблюдений (Ekman, Griesser, 2016). По срокам дисперсии среди сеголетков выделяют две категории птиц - «ранних дисперсантов», покидающих родительский участок в течение 4-7 недель после вылета из гнезда, и «поздних», остающихся с родителями на зиму. Основной причиной дисперсии считают пищевую конкуренцию между птенцами (Ekman et al., 2002).

На площадке № 2 из 99 окольцованных слетков кукши сведения об их местопребывании получены у 17 особей. Три птицы в возрасте 1.5- 
4.5 года из четырех, покинувших площадку, держались на удалении от места рождения, соответственно, в 250-470 м (2 встречи), 1800-2000, в среднем 1900 м (3) и 370-1100, в среднем 930 м (9 встреч). Из 13 сохранившихся на площадке к октябрю 2015 г. птиц, у пяти в возрасте 1-4.5 года величина дисперсии колебалась примерно от 200 до 1300 м, составляя в среднем 700 м (17 встреч), у 8 сеголетков - от 60 до 4000, в среднем 800 м (9 встреч). В полугодовалом возрасте птицы $(\mathrm{n}=15)$ держались в 60-4000 м (в среднем 700 м от места рождения; 16 встреч), 1-1.5 лет $(\mathrm{n}=8)$ - 200-2000 м (в среднем 800 м; 14 встреч), 2-2.5 лет $(\mathrm{n}=4)-700-2000$ м (в среднем 1000 м; 5 встреч), 3-3.5 года $(\mathrm{n}=2)-1000$ 1400 м (в среднем 1200 м; 2 встречи), 4-4.5 лет $(\mathrm{n}=2)-900-1300$ м (в среднем 1000 м; 3 встречи). Таким образом, натальная дисперсия у 16 разновозрастных птиц составила 60-4000 м (в среднем 800 м; 40 встреч).

В Фенноскандии натальная дисперсия может достигать 290 км, но в среднем она составляет 2.4 км (Uimaniemi, 2004). При этом среднее удаление ранних «дисперсантов» в Швеции $-9.0 \pm$ 2.6 км (Ekman et al., 2002), максимальное - 72 км, а поздних - 125 км (Griesser et al., 2014).

Данные о времени дисперсии и первого гнездования птенцов, приводимые по Кандалакшскому заповеднику (Коханов, 1982), показывают, что из 9 помеченных на территории заповедника птенцов семь покинули родителей в возрасте около года, один - в 0.5 , один - в 1.5 лет. Три из них заняли участки на удалении 0.5-1 км от места рождения, два загнездились в возрасте 3 лет, прожив по году с родителями, а затем два последующих - в парах, не размножаясь, уже на собственных территориях.

На площадке № 2 из 17 осевших на ней местных сеголетков лишь один - самец (комбинация цветных колец «ВВРМ»), уже на втором году образовал пару с самкой «PLgRM». В 2011 г. он отмечался с ней у недостроенного гнезда на соседнем с родителями участке (дальность дисперсии - 890 м), в 2012 г. эта пара успешно гнездилась (гнездо № 4, 70 м). В 2014 г. птицы снова гнездились, но неудачно (гнездо № 6, впоследствии разоренное, 73 м). Еще одна птица в возрасте 2 лет («VMOV») в 2015 г. держалась с родителями на их гнездовом участке (гнездо № 13).

Гнездовая дисперсия у 25 пар, загнездившихся с первой попытки, составила 15-770, в среднем 250 м, n = 43). У птиц, имеющих за сезон по нескольку гнезд (ложных, недостроенных или повторно-вынужденных), разброс гнезд варьировал между 16 и 400 м (в среднем 200 м, n = 25). Пары, сформированные после утраты участка предыдущего партнера, гнездились в 50-
640 м (в среднем 250 м от места последнего размножения, $\mathrm{n}=6$ ).

На площадке № 1 в марте 1988 г. три одиночных «иммигранта»: две самки и самец, присоединились к местным парам в качестве третьего партнера. Через три года одна из самок образовала пару с «иммигрантом» и загнездилась в 1.5 км от места кольцевания и в 1 км от последнего гнезда «приемной» пары. Вторая самка была обнаружена на гнездовье через год в 740 м от места отлова. Третья птица - самец, год спустя после регистрации, в паре с неудачно размножавшейся здесь и, судя по всему, потерявшей партнера самкой устроили гнездо в 720 м от места кольцевания. Инициатором выбора территории, вероятно, также являлась самка, занимавшая ранее соседний участок.

\section{ЗАКЛЮЧЕНИЕ}

Широко распространенные в лесной зоне Евразии кукши обитают в разнообразных ландшафтно-экологических условиях, что отражается на параметрах населения и воспроизводства вида, характере его территориальных связей (Гермогенов и др., 2017; Егоров и др., 2019) В северных частях ареала кукши, вероятно, откочевывают на зиму к югу либо дважды в год совершают локальные сезонные кочевки - в конце осени - начале зимы (прежде всего сеголетки) и в конце зимы - весной (в основном молодые птицы, находящиеся в поиске собственной территории обитания и гнездования).

В европейской части ареала вида и на Колыме пары занимают близкие по размерам территории обитания - от 45-75 до 100-150 га (Blomgren, 1971; Кречмар и др., 1978; Андреев, 1980; Коханов, 1982; Правосудов, 1984), их величина максимальна в зимнее время (Blomgren, 1971).

На площадках в Якутии пары-«резиденты» держатся в районе месторасположения своих гнезд постоянно, на перекрывающихся с соседями территориях обитания. Их площадь составляет в среднем $52 \pm 9$ га. Конспецифических особей можно встретить в любой части территории пары лишь вне гнездового и выводкового периодов.

По расчетным данным, средний размер гнездового участка пары составляет 41.2 га, при вычете из площади занимаемых местообитаний крупных открытых пространств он меньше 31.6 га. Пары гнездятся в определенных местах участка, отличающихся наилучшими для размножения условиями. Места размещения гнезд (от одного до нескольких на участок) в среднем занимали $2.9 \pm 0.4$ га, у многократно гнездившихся пар площадь их значительно меньше $-1.8 \pm 0.4$ га. Территориально определившиеся птицы способны менять предпочтения не только в выборе гнез- 
довых биотопов, но и в отношении мест расnоложения гнезд, даже в условиях одного и того же гнездового участка. Продолжительность занятости гнездовых участков (не всегда одними и теми же парами) варьировала от $1.86 \pm 0.14$ (площадка № 1) до $4.7 \pm 0.31$ сезона (площадка № 2). Гнездовой консерватизм прослеживается у них в 78.3\% случаев гнездования. Смена участков отмечалась преимущественно в парах, где произошла замена партнера.

При выборе древесной или кустарниковой породы для строительства гнезда пары менее консервативны. На площадке № 1 птицы предпочитали строить гнезда преимущественно на соснах $(62.6 \%)$ и лиственницах (33.0) $(\mathrm{n}=91)$. Вероятность смены пород составляла около $50 \%$. На площадке № 2 гнезда располагались чаще на кустарниковых ивах (56.9) и лиственницах (35.4) $(\mathrm{n}=144)$. Одну и ту же гнездовую породу использовали 12 из 25 пар (48\%).

В условиях Якутии натальная дисперсия составила 60-4000 м (в среднем 800 м). Здесь она значительно меньше, чем в Фенноскандии в целом (по: Uimaniemi, 2004) - до 290 км, в среднем 2.4 , приближаясь к таковой поздних «дисперсантов» в Швеции - 1.25 км (Ekman et al., 2002). Это, вероятно, обусловлено отсутствием достаточного количества возвратов колец, получить которые для кукши в условиях малонаселенной тайги весьма проблематично. Разброс локаций гнезд (гнездовая дисперсия) у 25 пар составила 15-770 м (в среднем 250 м, $\mathrm{n}=43$ ). У птиц, имеющих за сезон по нескольку гнезд (ложных, повторно-вынужденных и т. д.), эта величина варьировала в пределах между 16 и 400 м (в среднем 200 м, $n=25)$. Сформированные в связи с утратой птицей-«хозяином» участка предыдущего партнера новые пары гнездились в 50-640 м (в среднем 250 м) от места последнего размножения.

Работа выполнена в рамках базового проекта ИБПК СО РАН на 2019-2021 гг. № 0376-2019-0004 AAAA-A17-117020110058-4 «Структура и динамика популяций и сообществ животных холодного региона Северо-Востока России в современных условиях глобального изменения климата и антропогенной трансформации северных экосистем: факторы, механизмы, адаптации, сохранение» (2019-2021 гг.).

\section{ЛИТЕРАТУРА}

Андреев А. В. Адаптации птиц к зимним условиям Субарктики. Москва : Наука, 1980. 176 с.

Владимирская М. И. Птицы Лапландского заповедника // Тр. заповедника. Москва : Совмин РСФСР, 1948. Вып. 3. С. 171-245.

Гермогенов Н. И., Егоров Н. Н., Ларионов А. Г., Секов А. Н., Макаров М. И. Фауна и население птиц в сельхозугодьях Лено-Вилюйского междуречья (на примере комплексной орнитологической площадки) // Птицы и сельское хозяйство: Материалы II
Междунар. орнитол. конф. «Птицы и сельское хозяйство: современное состояние, проблемы и перспективы изучения». Пос. Якорная Щель (Сочи), 1719 сент. 2018 г. С. 58-63.

Гермогенов Н. И., Егоров Н. Н., Секов А. Н. Экология гнездования кукши (Perisoreus infaustus, Passeriformes) в Якутии // Современные проблемы орнитологии Сибири и Центральной Азии : Материалы V Междунар. орнитол. конф. (18-20 мая 2012 г.). Улан-Удэ : Изд-во Бурят. ун-та, 2013. С. 186-190.

Гермогенов Н. И., Егоров Н. Н., Секов А. Н. Структура населения кукши Perisoreus infaustus в Центральной Якутии // Русский орнитологический журнал. 2014. № 23 (1013). C. 1894-1898.

Гермогенов Н. И., Егоров Н. Н., Секов А. Н., Лосоров A. B. Экология гнездования кукши Perisoreus infaustus (Corvidae) в Якутии // Вестник Северо-Восточного научного центра ДВО РАН. 2017. № 3. С. 100-114.

Гермогенов Н. И., Егоров Н. Н., Слепиов С. М., Сeков А. Н. Зимнее гнездование птиц в Якутии / XIV Междунар. орнитол. конф. Северной Евразии. 1: тезисы. Алматы, 2015. С. 135-136.

Гермогенов Н. И., Находкин Н. А., Осипов И. Ю., Егоров H. H. Материалы по филопатрии кукши Perisoreus infaustus в Центральной Якутии // Наземные позвоночные Якутии: экология, распространение, численность. Якутск : ЯФ изд-ва СО РАН, 2002. C. 5-17.

Глани С. Медико-биологическая статистика. Москва : Практика, 1999. 459 с.

Егоров Н. Н., Гермогенов Н. И., Секов А. Н., Лосоров А. В. Численность и структура населения кукши (Perisoreus infaustus, Passeriformes, Aves) в Якутии // Вестник Северо-Восточного научного центра ДВО РАН. 2019. № 2. С. 73-88.

Ковшарь А. Ф. Певчие птицы в субвысокогорье Тянь-Шаня (очерки летней жизни фоновых видов). Алма-Ата : Наука, 1979. 312 с.

Коханов В. Д. К экологии кукши в Мурманской области // Экология и морфология птиц на крайнем северо-западе СССР : сб. науч. тр. ЦНИЛ Главохоты РСФСР. Москва, 1982. С. 124-137.

Кречмар А. В., Андреев А. В., Кондратьев А. Я. Экология и распространение птиц на северо-востоке СССР. Москва : Наука, 1978. 196 с.

Лакин Г. Ф. Биометрия : учеб. пособие для биологич. спец. вузов. Москва : Высш. шк., 1980. 293 с.

Ларионов Г. П., Гермогенов Н. И., Сидоров Б. И. Фауна и экология зимующих птиц Лено-Вилюйского междуречья // Фауна и экология наземных позвоночных таежной Якутии. Якутск : Изд-во ЯГУ, 1980. C. $85-141$.

Паевский В. А. Демографическая структура и популяционная динамика певчих птиц. Санкт-Петербург; Москва : Тов-во науч. изданий КМК, 2008. 235 с.

Правосудов В. В. О запасании пищи кукшей (Perisoreus infaustus, Passeriformes, Corvidae) в весенний период // Зоологический журнал. 1984. № 63 (6). C. $950-953$.

Рябицев В. К. Территориальные отношения и динамика сообществ птиц в Субарктике. Екатеринбург : Наука, Урал. отделение, 1993. 296 с.

Семенов-Тян-Шанский О. И., Гилязов А. С. Птицы Лапландии. Москва : Наука, 1991. 228 с. 
Соколов Л. В. Филопатрия перелетных птиц // Орнитология. 1988. Вып. 23. С. 11-25.

Blomgren A. Studies of less familiar birds. 162: Siberian jay // British Birds. 1971. 64. P. 25-28.

Cramp S., Perrins C. M. Handbook of the birds of Europe, the Middle East and North Africa. The birds of the western palearctic. Oxford : Oxford University Press, 1994. Vol. 8. P. 31-42.

Ekman J., Eggers S., Griesser M. Fighting to stay: the role of sibling rivalry for delayed dispersal // Animal Behavior. 2002. 64. P. 453-459.
Ekman Jan Bertil, Griesser Michael. Siberian jays: delayed dispersal in the absence of cooperative breeding. Chapter January 2016. P. 6-18.

Griesser M., Halvarsson P., Sahlman T., Ekman J. What are the strengths and limitations of direct and indirect assessment of dispersal? Insights from a longterm field study in a group-living bird species // Behavioral Ecology and Sociobiology. 2014. 68. P. 485-497.

Uimaniemi L. Maintenance of genetic diversity in four taiga specialists. Department of Biology, University of Oulu, P. O. Box 3000, FIN-90014 University of Oulu, Finland, 2004. 53 p.

Поступила в редакичюю 05.04.2019 2.

Поступила после доработки 05.02.20 г.

\title{
TERRITORIAL RELATIONS, NESTING CONSERVANCY, DISPERSION, AND PHILOPATRY OF THE SIBERIAN JAY PERISOREUS INFAUSTUS (PASSERIFORMES, AVES) IN YAKUTIA
}

\author{
N. N. Egorov, N. I. Germogenov, A. N. Sekov, A. V. Losorov \\ Institute for Biological Problems of Cryolithozone SB RAS, Yakutsk
}

\begin{abstract}
Studies were conducted within two species model sites (471 and $1360.3 \mathrm{ha}$ ) in the middle taiga light-coniferous forests near the city Yakutsk (62 N, 129 E) in 1975-2015. The Siberian jay inhabits a variety of landscape conditions and is very plastic when choosing a nesting site and a place for the nest. A significant part of breeding birds are characterized by conservatism manifested in the presence of permanent habitats with nesting sites and nesting locations. Individual tagging data indicate that most chicks left the model sites (were died or emigrated). Only a small percentage of young birds stayed within the local population, joining territorial pairs as a third "inert" partner, and later, having acquired a partner and a territory, being included in the reproductive population.
\end{abstract}

Keywords: Siberian jay, territorial connection, nest-site conservatism, natal and breeding dispersion, Central Yakutia.

\section{REFERENCES}

Andreev, A. V., 1980. Adaptations of the Birds to Winter Conditions of the Subarctic. Moscow, Nauka [In Russian].

Blomgren A., 1971. Studies of Less Familiar Birds, 162: Siberian Jay, British Birds. 64, 25-28.

Cramp, S., Perrins, C. M., 1994. Handbook of the Birds of Europe, the Middle East and North Africa, The Birds of the Western Palearctic. Oxford, Oxford University Press, VIII, 31-42.

Egorov, N. N., Germogenov, N. I., Sekov, A. N., Losorov, A. V., 2019. Population Size and Structure of Siberian Jay (Perisoreus infaustus, Passeriformes, Aves) in Yakutia, Bulletin of the North-East Science Center. 2, 73-88 [In Russian].

Ekman, J. B., Griesser, M., 2016. Siberian Jays: Delayed Dispersal in the Absence of Cooperative Breeding, January, 6-18.

Ekman, J., Eggers, S., Griesser, M., 2002. Fighting to Stay: the Role of Sibling Rivalry for Delayed Dispersal, Animal Behavior. 64, 453-459.
Germogenov, N. I., Egorov, N. N., Larionov, A. G., Sekov, A. N., Makarov, M. I., 2018. Fauna and Population of Birds in Farmlands of the Leno-Vilyui Interfluve (on the Example of a Complex Ornithological Research Area), Materials of the $2^{\text {nd }}$ International Ornithological Conference "Birds and Agriculture: Current State, Problems and Perspectives of Study", Yakornaya Shchel, Sept. 17-19. Sochi, 58-63 [In Russian].

Germogenov, N. I., Egorov, N. N., Sekov, A. N., 2013. Nesting Ecology of the Siberian Jay (Perisoreus infaustus, Passeriformes) in Yakutia, Materials of the $5^{\text {th }}$ International Ornithol. Conference, Modern Problems of Ornithology in Siberia and Central Asia, Ulan-Ude, May 18-20, 2012. Ulan-Ude, 186-190 [In Russian].

Germogenov, N. I., Egorov, N. N., Sekov, A. N., 2014. Population Structure of the Siberian Jay Perisoreus infaustus in Central Yakutia, Russian Journal of Ornithology. 23 (1013), 1894-1898 [In Russian].

Germogenov, N. I., Egorov, N. N., Sekov, A. N., Losorov, A. V., 2017. Nesting Ecology of the Siberian Jay 
Perisoreus infaustus (Corvide) in Yakutia, Vestnik SVNC DVO RAN. 3, 100-114 [In Russian].

Germogenov, N. I., Egorov, N. N., Sleptsov, S. M., Sekov, A. N., 2015. Winter Bird Nesting in Yakutia, $14^{\text {th }}$ International Ornithological Conference of Northern Eurasia. I, Almaty, 135-136 [In Russian].

Germogenov, N. I., Nakhodkin, N. A., Osipov, I. Yu., Egorov, N. N., 2002. Materials on Philopatry of the Siberian Jay Perisoreus infaustus in Central Yakutia, Terrestrial Vertebrates in Yakutia: Ecology, Distribution, Population, Scientific Works. Yakutsk, Yakutsk Division of SB RAS Press. 5-17 [In Russian].

Glants, S., 1999. Medical and Biological Statistics. Moscow, Praktika [In Russian].

Griesser, M., Halvarsson, P., Sahlman, T., Ekman, J., 2014. What are the Strengths and Limitations of Direct and Indirect Assessment of Dispersal? Insights from a Long-Term Field Study in a Group-Living Bird Species, Behavioral Ecology and Sociobiology. 68, 485-497.

Kokhanov, V. D., 1982. On the Ecology of Siberian Jay in Murmansk Oblast, Ecology and Morphology of Birds in Far North-East of the USSR, Collection of Scientific Papers of the Glavokhota Central Research Laboratory. Moscow, Nauka. 124-137 [In Russian].

Kovshar, A. F., 1979. Songbirds in the Sub-Highlands of the Tien Shan (Essays on Summer Life of Background Species). Alma-Ata, Nauka [In Russian].
Krechmar, A. V., Andreev, A. V., Kondratyev, A. Ya., 1978. Ecology and Distribution of Birds in the North-East of the USSR. Moscow, Nauka [In Russian].

Lakin, G. F., 1980. Biometry. Moscow, Vysshaya Shkola [In Russian].

Larionov, G. P., Germogenov, N. I., Sidorov, B. I., 1980. Fauna and Ecology of Wintering Birds of the LenaVilyui Interfluve, Fauna and Ecology of Nerrestrial Vertebrates in the Taiga of Yakutia. Yakutsk. 85-141 [In Russian].

Payevskiy, V. A., 2008. Demographic Structure and Population Dynamics of Songbirds. Moscow, KMK, Scientific Press [In Russian].

Pravosudov, V. V., 1984. On the Siberian Jay (Perisoreus infaustus, Passeriformes, Corvidae) Food Storage in Spring, Zoologicheskii Zhurnal. 63, 6, 950-953 [In Russian].

Ryabitsev, V. K., 1993. Territorial Relations and Dynamics of Bird Communities in the Subarctic. Yekaterinburg, Nauka [In Russian].

Semenov-Tyan-Shanskiy, O. I., Gilyazov, A. S., 1991.

Birds of Lapland. Moscow, Nauka [In Russian].

Sokolov, L. V., 1988. Philopatry of Migratory Birds, Ornithologia. 23, 11-25 [In Russian].

Uimaniemi, L., 2004. Maintenance of Genetic Diversity in Four Taiga Specialists, Acad. Diss., Oulu, Sweden.

Vladimirskaya, M. I., 1948. Birds of the Lapland Nature Reserve, Trudy Laplandskogo Zapovednika. Moscow, Sovmin RSFSR. 3, 171-245 [In Russian]. 